\title{
ARIN INAYAH
}

English Teaching Instruction for Non-English Learners

\section{MUHAMMAD FARHAN RAFI}

Teaching Speking with Reader's Theatre

\section{NOVI RAHMANIA AQUARIZA \& SYAFIUL ANAM}

Strengthening EFL Pre-Service Teacher's Pedagogic Competence

Through Extensive Reading

\section{NANIK SRI RAHAYU}

The Representative Activities of Multiple Intelligences in English Textbook 'When English Rings a Bell' for $8^{\text {th }}$ Graders

\section{RINA SARI \& NOVERITA WAHYUNINGSIH}

Utilizing Business Game for Improving Students'

Speaking Proficiency in Economics Faculty

\section{LULU LAELA AMALIA}

Reflective Practice and Self-Identity as Parts of Professional Development: A Survey in a Tertiary Level

\section{RIRYN FATMAWATY \& PUTRI AYU ANGGRAINI}

An Analysis of English Word Formation Processes

in Beats Apart Novel by Alanda Kariza

and KevinAditya

Diterbitkan oleh:

Fakultas Keguruan dan Ilmu Pendidikan

Program Studi Pendidikan Bahasa Inggris

Universitas Islam Lamongan 



\section{年 \\ Q-LINK JOURNAL FAKULTAS KEGURUAN DAN ILMU PENDIDIKAN UNIVERSITAS ISLAM LAMONGAN}

\section{Vol. 6 No. 01 Tahun 2019}

\section{DEWAN REDAKSI}

Penanggung Jawab

Ketua

Sekretaris

Editor Manajemen

Editor Tata Kelola

Reviewer
: Dr. Madekhan, S.Pd., M.Si.

: Abdullah Farih, M.Pd.

: Tiara Retno H., M.Pd.

: 1. Dian Luthfiyati, M.Pd.

2. Diah Astuty, M.Pd.

: 1. Riryn Fatmawaty, M.Pd.

2. Hariyanto, S.Pd., M.Ip.

: 1. Dr. Like Raskova Octaberlina, M.Ed. (UIN Maulana Malik Ibrahim Malang)

2. Siti Nurul Azkiyah, Ph.D. (UIN Syarif Hidayatullah Jakarta)

3. Sastika Seli, S.Pd., M.A. (STKIP Lubuk Linggau)

4. Ayu Oktaviani, S.Pd., M.A. (STKIP Lubuk Linggau)

\section{PENERBIT}

Fakultas Keguruan dan Ilmu Pendidikan Program Studi Pendidikan Bahasa Inggris Universitas Islam Lamongan

\section{KANTOR}

Fakultas Keguruan dan Ilmu Pendidikan Gedung A Universitas Islam Lamongan Jl. Veteran No. 53 A Lamongan

Telp. (0322)324706/ 317116.

Email: fkipunisla@gmail.com 



 \\ Q-LINK JOURNAL FAKULTAS KEGURUAN DAN ILMU PENDIDIKAN UNIVERSITAS ISLAM LAMONGAN}

\section{Vol. 6 No. 01 Tahun 2019}

\section{ARIN INAYAH}

English Teaching Instruction for Non-English Learners (117-126)

\section{MUHAMMAD FARHAN RAFI}

Teaching Speking with Reader's Theatre (127-133)

\section{NOVI RAHMANIA AQUARIZA \& SYAFIUL ANAM}

Strengthening EFL Pre-Service Teacher's Pedagogic Competence

Through Extensive Reading (134-137)

\section{NANIK SRI RAHAYU}

The Representative Activities of Multiple Intelligences in English Textbook 'When English Rings a Bell' for $8^{\text {th }}$ Graders (138-147)

\section{RINA SARI \& NOVERITA WAHYUNINGSIH}

Utilizing Business Game for Improving Students'

Speaking Proficiency in Economics Faculty (148-159)

\section{LULU LAELA AMALIA}

Reflective Practice and Self-Identity as Parts of Professional Development: A Survey in a Tertiary Level (160-163)

\section{RIRYN FATMAWATY \& PUTRI AYU ANGGRAINI}

An Analysis of English Word Formation Processes

in Beats Apart Novel by Alanda Kariza

and KevinAditya (164-182) 


\title{
THE REPRESENTATIVE ACTIVITIES OF MULTIPLE INTELLIGENCES IN ENGLISH TEXTBOOK 'WHEN ENGLISH RINGS A BELL' FOR 8 ${ }^{\text {TH }}$ GRADERS
}

\author{
Nanik Sri Rahayu \\ nanikmamaezra@gmail.com \\ Doctorate Program in English Language Teaching, Universitas Negeri Malang \\ Institut Agama Islam Negeri Tulungagung
}

\begin{abstract}
English textbook provided for eight graders is also renewed because of the latest curriculum, 2013 Curriculum. Regarding the theory of Multiple Intelligences, the textbook that the teachers used needs an evaluation in case of helping the teachers to face the students' diversity in learning style. To evaluate whether English textbook When English Rings a Bell' for $8^{\text {th }}$ Graders can be regarded as appropriate textbook based on the theory of Multiple Intelligences, this study is held. Thus, this study aims at investigating types of intelligence are included in the activities and what type of intelligences is most dominantly used in the activities provided in 'When English Rings a Bell' English Textbook for $8^{\text {th }}$ Graders. Content analysis is used as method in this study and to analyze the data Multiple Intelligence checklist. Among 364 activities analyzed, 105 activities belong to Bodily-Kinesthetic (BKI) which indicated $28,85 \%$ as the greatest percentage.
\end{abstract}

\section{Keywords: Multiple intelligence, Teaching and learning activities, Textbook}

\section{INTRODUCTION}

English Language Teaching (ELT) in Indonesia is recently changed due to the curriculum renewal. The current curriculum, 2013 Curriculum, as the completion of Competency-Based Curriculum (KBK-2014), promotes some changes related to English subject. In English subject, besides the changes of the standard content, there are some other significant changes in 2013 Curriculum. The Ministry of Education and Culture made those changes that include: (1) removal of English subject from elementary school, (2) reduction of teaching hours at senior high school, (3) reduction of contents of teaching materials (types of texts and speech acts), (5) limitation of topics of discussion, (6) explicit addition of grammar points, (7) integration of all language skills, and (8) reduction of teachers' duties in material and curriculum development. Therefore, there must be some interrelated consequences of these changes on how the teaching of English in Indonesia will be like. Those consequences can be challenges to improve the teachers' teaching performance.

As the previous curriculum, the implementation of 2013 Curriculum in Indonesia also considers the use of English textbook. Textbook is an effective resource for self-directed learning, an effective source of presentation of materials, a source of ideas and activities, a reference source for students, a syllabus where they reflect predetermined language objectives, and support for less experienced teachers who have yet to gain confidence (Cunningsworth in Awasthi, 2009:1).

Textbooks play some important roles in foreign language learning and teaching. They can provide structure and syllabus for a program, help standardize instruction, maintain quality, provide a variety of learning resources, provide effective language models and input, and train teachers. Further, they are also efficient and visually appealing (Richards, 2001:1-2). In addition, Ur cited in Awasthi (2009:3), also gives some arguments to support the benefits of using textbook. 
They are (i) a textbook is a frame work which regulates and times the programs; (ii) in the eyes of the learners, no textbooks means no purpose; (iii) without a textbook, learners think their learning is not taken seriously; (iv) a textbook provides ready texts and learning tasks; (v) a textbook is a cheap way of providing learning materials; (vi) a learner without a textbook is out of focus and teacherdependent, and perhaps most important of all; (vii) for novice teachers a textbook means security, guidance and support.

Further, Richards (2001:2) also lists some limitations of using textbooks. Textbooks can give potensial negative effects because they may contain inauthentic language, distort content, not reflect students' ${ }^{6}$ needs, deskill teachers, and they are probably expensive.

In the same way, Ur quoted in Awasthi (2009:4), also gives some disadvantages of using textbooks. They are: (i) if every group of students has different needs, no textbook can be a response to all differing needs; (ii) topics in a textbook may not be relevant for and interesting to all; (iii) a textbook is confining i.e. it inhibits teachers' creativity; (iv) a textbook of necessity sets prearranged sequence and structure that may be realistic; (v) textbooks have their own rationale, and as such they cannot by their nature cater for a variety of levels, every type of learning styles, and every category of learning strategies that often exist in the class, and most important of all, perhaps; (vi) teachers may find themselves as mediators with no free hand and slave, in fact, to others' judgments about what is good and what is not.

Textbook evaluation is very important due to some factors, as mentioned by Richards (2001:4), they are program factors (questions relating to concerns of the program), teacher factors (questions relating to teacher concerns), learner factors (questions relating to learner concerns), content factors (questions relating to the content and organization of the material in the book), pedagogical factors (questions relating to the principles underlying the materials and the pedagogical design of the materials, including choice of activities and exercise types. While some criteria for evaluating textbook also has been proposed by Cunningsworth as cited in Richards (2001:4). Those criteria are mainly focused on the students' need.

It is known, as individual, student varies in leaning style and preference. This condition is promoted by the predominant intelligence she/he has. Gardner (1993) proposes the existence of at least seven basic intelligences. More recently, cited in Armstrong (2009:6), Gardner has added an eighth and discussed the possibility of a ninth. The different type of intelligeces can also effect the result of language learning. For instance, student $\mathrm{A}$ has linguistic intelligence as his predominant intelligence, while student B has logicalmathematical intelligence as his predominant intelligence. It is sure that student A likes learning language much more than student $\mathrm{B}$, unless student $\mathrm{B}$ finds the way he like to learn it. This condition happens since every student has his/her own portion on the combination of intelligences she/he has. They differ in their predominant intelligence. Those students' profiles will eventually promote their each interest on the way to learn something. Therefore, it will be the big challenge for language teacher to know and plan the appropriateness of activities provided in textbook by considering the students' profiles.

Organizing teaching with the Multiple Intelligence theory can promote various teaching ideas and interest the students in their studies. It will give a chance for everyone to shine and feel comfortable in the classroom. The teaching becomes more like the real world and gives students opportunities to develop their special abilities which are very useful 
in later life (Sólmundardóttir, 2008:29). That is why language teachers today have to be aware that students have different strengths, learning styles and even learning potentials. Language teachers also must be familiar with the Multiple Intelligence theory in order to be able to teach students effectively in different ways.

Regarding all the statements explained above, the researcher tries to analyze the apropriateness of the activities, tasks and instructions presented in the current textbook of 2013 Curriculum with the need of students' profils. The researcher also takes the consideration that English is taught as Foreign Language in Junior High School. In Junior High School, language teachers will meet the students with many differences since the specialization groups such as Natural sciences class, Social sciences class, and Language and literature class do not exist yet. Those also will be the reason why the textbook used must provide activities which represent all the students' differences.

'When English Rings a Bell', English textbooks for grade 7 and 8 provided by the Ministry of Education and Culture are taught using scientific approach. In scientific approach, it consists of learning phases constructed from observing, questioning, collecting information/experimenting, associating, and communicating (Kementrian Pendidikan dan Kebudayaan, 2013d). Further, there are also some activities included in those phases.

The roles of textbooks in English Language Teaching (ELT) in Indonesia are considered important. A textbook represents for both students and teachers the visible heart of any ELT program (Sheldon, 1988:237)[6]. It is also teaching material and a guide for a teacher, a learning material and a memory aid for a learner, and also a permanent record or measure of what has been learnt (Awasthi, 2006:1). Moreover, a textbook can serve different purposes for teachers: as a core resource, as a source of supplemental material, as an inspiration for classroom activities, even as the curriculum itself (Garinger, 2002).

Besides the important roles of textbook, many researchers also remind the negative effects of using textbook improperly. They believe that teachers will find many challenges to adjust the textbook with the real condition where they teach. Richards (2001:2) states that both the benefits and limitations of the use of textbooks needs to be considered, and if the textbooks that are being used in a program potentially have some negative effects, remedial action should be taken, e.g. by adapting or supplementing books or by providing appropriate guidance and support for teachers in how to use them appropriately.

According to Cunningswoth and Ellis, as quoted in Awasthi (2009:5), textbook evaluation helps teachers move beyond impressionistic assessments and it further facilitates them to acquire useful, accurate, systematic, and contextual insights into the overall nature of textbook materials. Textbook evaluation gives much more advantages because it can make a teacher knows the content of the book, the style in which it is written, and its strength and weaknesses, which facilitate him/her to adapt it to suit the course aims, learners' needs and the teachers' beliefs (Awasthi, 2009:5).

To have textbook evaluation, Richards (2001) proposes some information related to some issues must be known before it is taken place. First, one has to know the role of the textbook in the program. This issue includes some questions such as: (a) Is there a well developed curriculum which describes the objectives, syllabus and content of the program or will this be determined by the textbook?; (b) Will the book or textbook series provide the core of the program, or is it one of several different books that will 
be used?; (c) Will it be used with small classes or large ones?; (d) Will learners be expected to buy a workbook as well or should the textbook provide all the practice students need?

Second, textbook evaluation requires one to know the teachers in the program which is related to some questions such as: (a) How experienced are the teachers in the program and what is their level of training?; (b) Are they native speakers of English? If not, how well do they speak English?; (c) Do teachers tend to follow the textbook closely or do they use the book simply as a resource?; (d) Do teachers play a part in selecting the books they teach from? and; (e) Are teachers free to adapt and supplement the book?

The last issue is about the learners in the program which is related to some questions such as: (a) Is each student required to buy a book?; (b) What do learners typically expect in a textbook?; (c) Will they use the book in class and at home?; (d) How will they use the book in class? Is it the primary source of classroom activities? and; (e) How much are they prepared to pay for a book?

In addition, Cunningsworth, as cited in Richards (2001:4), proposes four criteria for evaluating textbooks, particularly course books:

1. They should correspond to learner's needs. They should match the aims and objectives of the languagelearning program.

2. They should reflect the uses (present or future) which learners will make of the language. Textbooks should be chosen that will help equip students to use language effectively for their own purposes.

3. They should take account of students needs as learners and should facilitate their learning processes, without dogmatically imposing a rigid .method.

4. They should have a clear role as a support for learning. Like teachers, they mediate between the target language and the learner.

Based on the fourth criteria of tetxbook evaluation mention above, it can be concluded that mostly textbook evaluation is done because of the needs of students'. Even though the textbook evaluation is done with many different purposes, one who is doing evaluation must be influenced by some factors due to some different situation. Each situation will require some questions to make the evaluation meaningful. Richards (2001:4) proposes that program factors need questions relating to concerns of the program, teacher factors need questions relating to teacher concerns, learner factors need questions relating to learner concerns, content factors need questions relating to the content and organization of the material in the book, and pedagogical factors need questions relating to the principles underlying the materials and the pedagogical design of the materials, including choice of activities and exercise types.

Finally, textbook needs an evaluation because it must be used in proper ways to reduce the potential negative effects toward the students' learning result.

\section{METHOD}

Descriptive qualitative design. In addition, this study also belongs to content or document analysis. As the type of qualitative research, content or document analysis is used to analyze and identify specified characteristics of the material which can be in form of textbooks, newspapers, and so on (Ary, et al., 2010)[8]. The researcher analyzes multiple intelligences types which are applied by the activities and tasks provided on the textbook and gives description and interpretation of the quality of the book based on the theory of Multiple Intelligences. 
The technique to collect the data of this study is document review or documentation. According to Ary, et al. (2010:442), documents can be classified into four categories: (1) public records, (2) personal documents, (3) physical materials, and (4) researcher-generated documents. While in this research, the researcher uses written or text-based artifacts in form of textbook which can also be categorized as public records.

In addition, the researcher also uses some abbreviation as follows to simplify the data;
a. WERaB $8^{\text {th }}$ graders means the title of textbook analyzed
b. chp means chapter
c. pg means page
d. MI means Multiple Intelligences
e. LI means Linguistic Intelligence
f. LMI means Logical-Mathematical Intelligence
g. SpI means Spatial Intelligence
h. McI means Musical Intelligence
i. BKI means Bodily-Kinesthetic
j. Inter-I means Interpersonal Intelligence
k. Intra-I means Intrapersonal Intelligence
1. NI means Naturalistic Intelligence

\section{DISCUSSION}

\section{Types of intelligences found in English Textbook 'When English Rings a Bell' for $8^{\text {th }}$ Graders}

Having analyzed the activities of English textbook 'When English Rings a Bell' for $8^{\text {th }}$ Graders, the researcher found that eight types of Multiple Intelligences were included in 364 activities provided by the textbook. However, they were different in number and not equally distributed in each chapter.

Based on the complete analysis, the researcher found that the number of each intelligence were greatly different and they were ranked from the greatest number. It is shown that first position belongs to
Bodily-Kinesthetic (BKI) which takes $28,85 \%$. The second one belongs to Linguistic Intelligence (LI) which takes $24,45 \%$. The third one is Spatial Intelligence (SpI) which takes 20,33\%. The fourth one is Logical-Mathematical Intelligence (LMI) which takes 9,9\%. The fifth one goes to Interpersonal Intelligence (Inter-I) which takes 6,59\%. The sixth one is Intrapersonal Intelligence (Intra-I) which takes $5,77 \%$. Then, the seventh one is Musical Intelligence (McI) which takes $2,19 \%$, and the last one is Naturalistic Intelligence (NI) which takes $1,92 \%$.

Besides the number of each type of intelligences, the researcher also found that all of those types were not equally distributed in some chapters. Some of Intelligences were provided in all chapters, while some them were only available in few chapters. Some of Intelligences even were not provided in certain chapters, such as, Musical Intelligence which was not available in chapter 1-8 and also in chapter 10-11. The other intelligence was Naturalistic Intelligence which was provided in the smallest number. It was only found in chapter 5 and 6 .

The following data show how they were distributed in some chapters.

a. Linguistic Intelligence

According to Armstrong (2009:10), Linguistic Intelligence deals with sensitivity to the sounds, structure, meanings, and functions of words and language. In this study, the researcher analyzed activities which were related to Linguistic Intelligence based on Multiple Intelligence Checklist used.

The researcher found 89 activities which represented Linguistic Intelligence. The representative activities of Linguistic Intelligence found in the textbook analyzed were available in all chapters of the textbook. However, the number of activities varied in every chapter. The greatest number of Linguistic Intelligence activity was found in chapter 9. The following table shows the Linguistic 
Intelligence activities found in the textbook analyzed.

b. Logical-Mathematical Intelligence

According to Armstrong (2009:10), Logical-Mathematical Intelligence deals with sensitivity to, and capacity to discern, logical or numerical patterns; ability to handle long chains of reasoning. In this study, the researcher analyzed activities which were related to LogicalMathematical Intelligence based on Multiple Intelligence Checklist used.

The researcher found 36 activities which represented Logical-Mathematical Intelligence. The representative activities of Logical-Mathematical Intelligence found in the textbook analyzed were available in all chapters of the textbook. However, the number of those activities varied in every chapter. The greatest number of Logical-Mathematical Intelligence activities was found in chapter 7. The following table shows the LogicalMathematical Intelligence activities found in the textbook analyzed.

c. Spatial Intelligence

According to Armstrong (2009:10), Spatial Intelligence deals with the capacity to perceive the visual-spatial world accurately and to perform transformations on one's initial perceptions. In this research, the researcher analyzed activities which were related to Spatial Intelligence based on Multiple Intelligence Checklist used.

The researcher found 74 activities which represented Spatial Intelligence. The representative activities of Spatial Intelligence found in the textbook analyzed were available in all chapters of the textbook. However, the number of those activities varied in every chapter. The greatest number of Spatial Intelligence activities was found in chapter 6 . The following table shows the Spatial Intelligence activities found in the textbook analyzed.

d. Musical Intelligence
According to Armstrong (2009:11), Musical Intelligence deals with Ability to produce and appreciate rhythm, pitch, and timbre; appreciation of the forms of musical expressiveness. In this research, the researcher analyzed activities which were related to Musical Intelligence based on Multiple Intelligence Checklist used.

The researcher only found 8 activities which represented Musical Intelligence. The representative activities of Musical Intelligence found in the textbook analyzed were available in all chapters of the textbook. However, the number of those activities varied in every chapter. The greatest number of Musical Intelligence activities was found in chapter 9 and the last unit.

e. Bodily-Kinesthetic

According to Armstrong (2009:10), Bodily-Kinesthetic Intelligence deals with ability to control one's body movements and to handle objects skillfully. In this research, the researcher analyzed activities which were related to Bodily-Kinesthetic Intelligence based on Multiple Intelligence Checklist used.

Further, the researcher found 105 activities which represented BodilyKinesthetic Intelligence. The representative activities of BodilyKinesthetic Intelligence found in the textbook analyzed were available in all chapters of the textbook. However, the number of those activities varied in every chapter.

f. Interpersonal Intelligence

According to Armstrong (2009:11), Interpersonal Intelligence deals with capacity to discern and respond appropriately to the moods, temperaments, motivations, and desires of other people. In this study, the researcher analyzed activities which were related to Interpersonal Intelligence based on Multiple Intelligence Checklist used.

The researcher found 24 activities which represented Interpersonal Intelligence. The representative activities 
of Interpersonal Intelligence found in the textbook analyzed were available in all chapters of the textbook.

g. Intrapersonal Intelligence

According to Armstrong (2009:11), Intrapersonal Intelligence deals with access to one's own "feeling" life and the ability to discriminate among one's emotions; knowledge of one's own strengths and weaknesses. In this research, the researcher analyzed activities which were related to Intrapersonal Intelligence based on Multiple Intelligence Checklist used.

The researcher found 21 activities
which Intelligence. The representative activities of Intrapersonal Intelligence found in the textbook analyzed was available in all chapters of the textbook. However, the number of those activities varied in every chapter. The greatest number of Intrapersonal Intelligence activities was found in chapter 7, 9, and 10. The following table shows the Intrapersonal Intelligence activities found in the textbook analyzed.

h. Naturalistic Intelligence

According to Armstrong (2009:11), Naturalistic Intelligence deals with expertise in distinguishing among members of a species; recognizing the existence of other neighboring species; and charting the relations, formally or informally, among several species. In this research, the researcher analyzed activities which were related to Naturalistic Intelligence based on Multiple Intelligence Checklist used.
The researcher found 21 activities which represented Naturalistic Intelligence. The representative activities of Naturalistic Intelligence found in the textbook analyzed were available in all chapters of the textbook. However, the number of those activities varied in every chapter. The greatest number of Naturalistic Intelligence activities was found in chapter 5 .

In short, it can be stated that Linguistic Intelligence is mostly presented in chapter 7 and 9 which has 13 activities in each chapter. Then, LogicalMathematical Intelligence is dominant in chapter 7 which has 8 activities. Spatial Intelligence is most often found in chapter 6 which is represented by 13 activities. Meanwhile, Musical Intelligence is mainly found in chapter 9 and additional unit which has 3 activities in each chapter. Then, Bodily-Kinesthetic is dominated by 17 activities in chapter 7 .

Interpersonal Intelligence has greatest number in chapter 9 which is represented by 6 activities. Then, Intrapersonal Intelligence is represented by 3 activities which is found in chapter 7, 9, and 10. The last type is Naturalistic Intelligence which is mostly presented in chapter 5 with 5 representative activities.

\section{The Dominant Type of Multiple Intelligence included in activities found in English Textbook 'When English Rings a Bell' for $8^{\text {th }}$ Graders}

The following table shows all activities analyzed which represent the existence of Multiple Intelligences found in the textbook.

Table 1. The Overall Percentages of Each Intelligence Occurrence

\begin{tabular}{|c|c|c|}
\hline $\begin{array}{l}\text { Multiple Intelligence Types Found } \\
\text { (364) } \\
\text { Linguistic Intelligence (LI) }\end{array}$ & $\begin{array}{c}\text { Number of Multiple } \\
\text { Intelligence Activities } \\
89\end{array}$ & $\begin{array}{c}\text { Percentage of Multiple Intelligence } \\
\text { Activities } \\
24,45 \%\end{array}$ \\
\hline No. & 36 & $9,9 \%$ \\
\hline Spatial Intelligence (SpI) & 74 & $20,33 \%$ \\
\hline Musical Intelligence (McI) & 8 & $2,19 \%$ \\
\hline
\end{tabular}


Bodily-Kinesthetic (BKI)

Interpersonal Intelligence (Inter-I)

Intrapersonal Intelligence (Intra-I)

Naturalistic Intelligence (NI)
105

24

21

7
$28,85 \%$

$6,59 \%$

$5,77 \%$

$1,92 \%$
From the data displayed above, the researcher can conclude that the most dominant intelligence types found in the textbook is Bodily-Kinesthetic Intelligences. It takes $28,85 \%$ of 364 activities found.

\section{Discussion}

According to the result of this study, it is known that all of eight types of Multiple Intelligences types are included in activities provided by the textbook. However, they are different in number. Besides the number of activities found, the researcher also focuses on how the activities presented in each chapter (see table1 4.1-4.8). The researcher considers that the distribution of activities in each chapter is not equal. In some chapters, it is even found that certain intelligence is not available. As figured by table 4.4 displayed above which shows the distribution of Musical Intelligence in each chapter. This Intelligence only appears in chapter 9 and the last unit. Meanwhile, the rest chapters do not present this Intelligence.

According to Taase (2012:77)[9], an English textbook is considered appropriate to use based on Multiple Intelligences when the representatives of each types of intelligence are proportionally distributed. Based on that argument, the researcher finally considers that English Textbook, 'When English Rings a Bells' for $8^{\text {th }}$ Graders is less appropriate to use based on Multiple Intelligences Theory.

Based on the data presented in data presentation, it is also found a suprising fact in this study. Some similar studies which are aimed to discover the Multiple Intelligence activities in English textbook show that Linguistic Intelligence is the most dominant. As the previous study mentioned in chapter II, the research which is conducted by Yoones Taase (2012) entitled Multiple Intelligences Theory and Iranian Textbooks: An Analysis, shows that between 64.13 $80.16 \%$ of activities analyzed are appropriate for students with Predominant Linguistic Intelligence (Yoones Taase, 2012:76). Meanwhile, in this research, it is found that Linguistic Intelligence occupies the second position after BodilyKinesthetic intelligence which takes $28,85 \%$ of all activities found.

Referring to Yoones Taase's argument, the researcher concludes that this textbook is appropriate enough if it is used for the students with BodilyKinesthetic Intelligence as their predominant intelligence. According to Hoerr, et al. (2010:76)[10], these students have some characteristics such as Dexterous, agile, enduring physical energy, quick, well-defined body control, takes in information through bodily sensations, hands-on learner, wellcoordinated motor skills, athletic, likes to figure out how things work, performer, demonstrates skill in crafts, uses body language, enjoys exhilarating experiences.

Hoerr also mentions some people with high portion of this Intelligence. Some of famous people he mentioned are Jim Carrey who uses his body to communicate emotions and humor in the many comedies in which he stars, Lebron James who displays talent and teamwork on the basketball court, Katherine Dunham who was an accomplished modern dancer and choreographer who founded her own dance company and school, and so on. 
Besides Bodily-Kinesthetic Intelligence which is the most dominant types of Multiple Intelligence in this textbook, the researcher also claims that Naturalist Intelligence is less dominant. This Intelligence is only represented by 7 activities which are only available in chapter 5 and chapter 6 . It is implied that this textbook is less appropriate to use for the students with Naturalistic Intelligence as their predominat intelligence.

According to Hoerr, et al. (2010:226), the students with Naturalistic Intelligence as their predominant Intelligence have some unique characteristics such as Learns through observation and discovery of natural phenomenon; good at comparing, categorizing, and sorting; enjoys being outdoors; excels in finding fine distinctions between similar items; feels alive when in contact with nature; appreciates scenic places; enjoys having pets; likes to camp, hike or climb; conscious of changes in the environment.

To show how unique this intelligence, Hoerr (2010) also mentions some famous people with this intelligence as their predominant intelligence as well. They are John Burroughs who was a naturalist important in the evolution of the conservation movement, Al Gore who was the former U.S. vice president, also an environmental activist who shared the 2007 Nobel Peace Prize with the Intergovernmental Panel on Climate Change, and many other people with this intelligence as their predominant Intelligence.

Finally, the researcher concludes that the textbook may need more teachers' creativity to modify the activities provided. It is done in order to make the appropriateness with their students' different needs in learning styles relate to the theory of Multiple Intelligences.

\section{COUNCLUSION}

Multiple Intelligences types are included in activities provided by textbook. From all of the activities analyzed, Bodily-Kinesthetic (BKI) takes $28,85 \%$, Linguistic Intelligence (LI) takes $24,45 \%$, Spatial Intelligence (SpI) takes 20,33\%, Logical-Mathematical Intelligence (LMI) takes 9,9\%, Interpersonal (Inter-I) takes 6,59\%, Intrapersonal Intelligence (Intra-I) takes $5,77 \%$, Musical Intelligence (McI) takes $2,19 \%$, and Naturalistic Intelligence (NI) takes 1,92\%. Eventually, the most dominant intelligence included in activities provided by the textbook is BodilyKinesthetic (BKI). From 364 activities analyzed, 105 activities belong to BodilyKinesthetic (BKI) which take $28,85 \%$ as the greatest percentage.

\section{REFERENCES}

Awasthi, Jai R. (2006) Textbook and its Evaluation. Journal of NELTA Vol. 11 , 2009, No. 1-2 December . pp.110 ,

Richards, Jack C. The Role of Textbooks in a Language Program, 2001, Retrieved on June $10^{\text {th }}, 2019$, from: www.professorjackricahrds.com

Armstrong, Thomas. (2003) The Multiple Intelligences of Reading and Writing: Making the Words Come Alive. Alexandria, Virginia: Association for Supervision and Curriculum Development (ASCD)

Sólmundardóttir, Anna S. (2008) The Multiple Intelligence Theory in English Language Teaching: ThemeBased Lesson Plans on Halloween. 240683-5399.Kennaraháskóli Íslands_Kennarabraut,grunnskólaken narafræði.

Available_online_at:http://skemman. is/stream/get/1946/1485/4473/1/adal _adal.pdf 
Kementrian Pendidikan dan Kebudayaan. Peraturan Menteri Pendidikan Dan Kebudayaan No 81a Tahun 2013 Tentang Implementasi Kurikulum 2013. Jakarta: Depdikbud.2013d

Sheldon, Leslie E. (1988). Evaluating ELT Textbooks and Materials. ELT Journal Volume 42/4 October 1988Oxford University Press.

Garinger, Dawn. 2002. Textbook Selection for the EFL Classroom. Washington DC: ERIC Digest (Dec.).

Ary, Donald et al. (2010). Introduction to Research in Education. 8th edition.
Canada:Wadsworth

Learning. 2010

Taase, Yoones. (2012). Multiple Intelligence Theory and Iranian Textbooks: An Analysis. Journal of Pan-Pacific Association of Applied Linguistics, 16(1), 73-82.

Hoerr, Thomas R. et al. (2010). Celebrating Every Learner : Activities and Strategies For Creating A Multiple Intelligences Classroom / Foreword By Howard Gardner. San Francisco: JosseyBass- A Wiley Imprint. 